consistent with the requisite strength. Hollow bricks, light tiles, with papier-maché for internal decorations, have been recommended as materials suitable for superstructures. At the present time the city of Manila, partly through Government interference, and partly through the desire of the inhabitants to reduce the chances of farther disasters, presents a singular appearance of light superstructures rising from old foundations. Iron roofs are visible in all directions, whilst on the massive basements of old cathedrals and churches upper stories of wood, with cupolas and spires of corrugated iron, have been erected.

Although the suggestions embodied in the above notes are few in number, it is hoped that they may be of some practical value. Without extending them, they show us that, even though we may not be in the position to escape from earthquakes by forewarning ourselves of their approach, we can at least mitigate the effects of these disasters by proper construction.

JOHN MILNE

Tokio

THE LATE ERUPTION OF VESUVIUS

$\mathrm{O}$

UR visit to the crater of Vesuvius on January II, I884, was a most interesting one. In my former letter I gave the rough details of this new eruption as well as could be ascertained from the base of the cone. The lava that issued on Tuesday night continued to flow till Wednesday evening, but seemed to have arrested its progress about Io o'clock that night, when I was in the Atrio del Cavallo. This stream proved to have welled out at the base of the little cone of eruption and to have flowed across the solid lava plain in the crater of 1872 , and then to have poured down the north-north-west slope of the cone till it reached the Atrio, across which it extended but little. Within the crater of I 872 we have a somewhat convex plain of lava, which is continuous with, or, more properly, overlaps, the crater edges, except for a short distance on the south-south-west side. The northeast part of this is covered by the remnants of the crater of January, I882. Within this were a series of crater rings that have since filled up to a certain extent the cavity of I882. For some time the vent has travelled south, so that the present cone of eruption overlaps the crater ring of January, 1882, on its south side, whereas there is a deep crescentic fossa between the present cone and the north crater ring of two years since. The vent was giving forth great volumes of vapour, and there was an almost continuous fountain of fragments of molten lava, which often attained the height of one or two hundred yards. As a consequence much filamentous lava, often as fine as cotton, was raining around the crater, and as we sat there eating our lunch, it was so covered with these rock fragments, that it required a long climb on foot to make such a gritty meal palatable. The ejectamenta are composed solely of lava in detached pieces, ejected in a plastic state with a few bombs, consisting of older solid lava fragments partially fused and rounded on the surface, which is varnished irregularly by the fluid magm? that enveloped them. This indicates that the lava is very near the top of the chimney, which must be full, as it has been for some time. Photography was no easy matter amidst this fiery bombardment, for such was the abundance of the ejectamenta that we could see how rapidly the cone of the eruption was growing. made a rough calculation of the quantity of new material expelled, and I think six cartloads in four seconds as quite a fair estimate. The lava that had finwed was solid and cold enough to allow my dog to cross it with ease, though through a few cracks it was seen to be still incandescent, and a green staff thrust in immediately blazed. The lava that was flowing in the direction of Pompeii is still doing so in one or two points, apparently at the same rate and place as two weeks since.
Altogether this eruption seems to be of very little importance, and during the last four years there have been many similar ones. Prof. Palmieri, in the Corrier: del Mattino of January II, prophesies a great eruption, but on what grounds it seems difficult to make out. No one would deny that such could occur and is not improbable; but there seems to be no more reason now than two months since.

The smoke or vapour yesterday had, when seen by reflected light, the same colour as usual, namely, a salmon tint. The sky was very clear, and I looked at the sun through this vapour, bearing in mind the recent remarkable sunsets and green suns. The transmitted light ranged from a burnt sienna brown to a dirty orange, having much the same colour as when we look through a dark London fog. I noticed that the light that traversed the vapour column and fell on the opposite escarpment of Monte Somma was of a colour that would be obtained by mixing a mauve with about equal quantities of brown.
Naples, January I 3
H. J. JohNSTON-LAvis

\section{THE EGYPTIAN SUDAN AND ITS INHABITANTS}

$A$ some degree of vagueness seems still attached to the term Sudan, it may be well to state at once that it is simply the Arabic equivalent of the older and more intelligible expressions, Nigritia, Negroland, which have in recent times somewhat unaccountably dropped out of use. In its widest sense it comprises the more or less fertile zone lying between the Atlantic on the one hand and the Red Sea and Abyssinian Highlands on the other, and stretching from the Sahara and Egypt Proper southwards to the Gulf of Guinea, the still unexplored Central Equatorial regions, and further east to Lakes Albert and Victoria Nyanza. 'This vast tract, which may on the whole be regarded as the true domain of the African Negro race, is commonly and conveniently divided into three great sections:-(I) Western Sutan, comprising roughly the basins of the Senegal and Quorra-Binue (Niger) with all the intervening lands draining to the Atlantic; (2) Central Sudan, co'nprising the basins of the Komadugu and Shari with all the lands (Kanem, Bornu, Baghirmi, Wadai) draining to Lake Chad; (3) Eastern Sudan, comprising everything east of Walai, that is mainly the Upper and Middle Nile basin.

Politically, this third section, with which alone we are here concerned, has for some years formed part of the Khedive's possessions, hence is now more generally known as Egyptian Sudan. Until 1882 it formed a single administrative division under a Governor-General resident at Khartum. But in that year a sort of Colonial Office was created for this region, which was placed under a Cabinet Minister and broken up into four separate cepartments or divisions, each under a Hukumdar, or Governor-General, directly responsible to the Minister for Sudan at Cairo. The various provinces hitherto forming the single administration of Egyptian Sudan thus became distributed as under :-

WEST SUDAN, comprising Darfur, KorJofan, Bahr-elGhazal, and Dongola, with capital Fasher.

CENTRAL SUDAN, comprising Khartum, Senaar, Berber. Fashoda, ant the Equator (Hat-el-Istwa), with capital Khartum.

EAST SUDAN, comprising Taka, Suakin, and Massowah, with capital Massowab.

HARRAR, comprising Zeyla, Berbera, and Harrar, with capital Harrar.

The complete development of this scheme has been somewhat rudely interrupted by the successful revolt of the "Mahdi," who has for the moment wrested the greater part of the country from Egyptian control. But should this arrangement be carried out after the restoration of order, a further element of confusion will be introduced 